\title{
TUBERCULOSIS IN POLISH ZOOS AS HEALTH RISK FOR HUMANS
}

\section{GRUŹLICA W POLSKICH OGRODACH ZOOLOGICZNYCH W ASPEKCIE ZDROWIA PUBLICZNEGO}

\author{
Monika Krajewska-Wędzina' ${ }^{1(\mathrm{~A}, \mathrm{~B}, \mathrm{C}, \mathrm{D}, \mathrm{E}, \mathrm{F}, \mathrm{G})}$, Ewa Augustynowicz-Kopećé ${ }^{2(\mathrm{C}, \mathrm{D}, \mathrm{E}, \mathrm{F})}$, \\ Marcin Weiner ${ }^{3(A, B, C, D, E, F)}$, Blanka Orłowska ${ }^{4(A, B, D, E)}$, Krzysztof Anusz $^{4(B, D, E)}$, \\ Krzysztof Szulowski ${ }^{1(\mathrm{D}, \mathrm{E}, \mathrm{G})}$
}

\author{
${ }^{1}$ Department of Microbiology, National Veterinary Research Institute in Pulawy, Poland \\ ${ }^{2}$ Department of Microbiology, National Tuberculosis and Lung Diseases Research Institute in Warsaw, Poland \\ ${ }^{3}$ Pope John Paul II State School of Higher Education in Biala Podlaska, Poland \\ ${ }^{4}$ Department of Food Hygiene and Public Health Protection, Faculty of Veterinary Medicine, \\ Warsaw University of Life Sciences, Poland
}

Authors' contribution Wkład autorów: A. Study design/planning zaplanowanie badań B. Data collection/entry zebranie danych C. Data analysis/statistics dane - analiza i statystyki D. Data interpretation interpretacja danych E. Preparation of manuscript przygotowanie artykułu F. Literature analysis/search wyszukiwanie i analiza literatury G. Funds collection zebranie funduszy
Tables: 2

Figures: 0

References: 29

Submitted: 2017 Sep 07

Accepted: 2017 Oct 25

\section{Summary}

Introduction. Tuberculosis is an infectious disease of humans and animals caused by the organism of the Mycobacterium tuberculosis complex (MTBC). It is one of the most widespread infectious diseases occurring in zoos. Taking into account the number of visitors to these sites, tuberculosis remains a major public health problem.

Material and methods. The study material consisted of lymph nodes, and internal organs collected post mortem from five zoo animals suspected of tuberculosis: antelope, two tapirs, alpaca and bison. The animals came from the zoos in Gdańsk, Wrocław and Chorzów. The microbiological analysis of 5 MTBC strains was performed to determine the molecular relationships among them.

Results. Five strains were isolated in the microbiological examination, 3 of which were identified as Mycobacterium bovis and 2 - as Mycobacterium caprae. 3 spoligotypes, i.e. SB1912, SB0856, SB2416, were obtained by spoligotyping. To confirm the transmission of tuberculosis in the studied animal population, the MIRU-VNTR method was applied. The unique patterns were assigned to 3 strains and the other 2 of the same pattern were assigned to one cluster, which would indicate the transmission of tuberculosis among animals.

Conclusions. The obtained results exclude the transmission of tuberculosis between zoos.

Keywords: zoonosis, Mycobacterium tuberculosis complex, tuberculosis, public health, transmission

\section{Streszczenie}

Wprowadzenie. Gruźlica jest zakaźną chorobą ludzi i zwierząt, którą powodują prątki wchodzace w skład kompleksu Mycobacterium tuberculosis (MTBC). Jest jedną z najbardziej rozpowszechnionych chorób zakaźnych występujących w zoo. Biorąc pod uwagę liczbę odwiedzających te miejsca, gruźlica stanowi niebezpieczeństwo dla zdrowia publicznego.

Materiał i metody. Materiał do badań stanowiły węzły chłonne i narządy wewnętrzne pobrane post mortem od pięciu zwierząt z zoo podejrzanych o gruźlicę: antylopy, dwóch tapirów anta, alpaki i żubra. Zwierzęta pochodziły z zoo w Gdańsku, Wrocławiu i Chorzowie. W pracy poddano analizie mikrobiologicznej 5 szczepów MTBC i określono pokrewieństwo molekularne pomiędzy nimi.

Wyniki. W wyniku badania mikrobiologicznego wyizolowano 5 szczepów, 3 zidentyfikowano jako M. bovis a 2 jako M. caprae. Metodą spoligotyping uzyskano 3 spoligotypy (SB1912, SB0856, SB2416). Do potwierdzenia zjawiska transmisji gruźlicy w badanej populacji zwierzat, zastosowano metode MIRU-VNTR. Wzory unikalne przyporzadkowano 3 szczepom, a pozostałe 2 szczepy o takich samych wzorach zostały przydzielone do wspólnego klasteru świadczącego o zaistniałej transmisji prątków gruźlicy pomiędzy zwierzętami.

Wnioski. Uzyskane wyniki pozwoliły wykluczyć transmisję gruźlicy między ogrodami zoologicznymi.

Słowa kluczowe: zoonoza, Mycobacterium tuberculosis complex, gruźlica, zdrowie publiczne, transmisja 


\section{Introduction}

Tuberculosis (TB) is an infectious disease of people and animals caused by mycobacteria of the Mycobacterium tuberculosis complex (MTBC) [1]. Currently, the MTBC consists of 11 species of mycobacteria which, in addition to the Mycobacterium bovis BCG vaccine strain, are pathogens for humans and animals. The last described species of the MTBC - Mycobacterium suricatte, is the etiologic agent in meerkats (Suricata suricatta) [2]. In Poland, tuberculosis is primarily caused by bovine bacilli: Mycobacterium bovis and Mycobacterium caprae [3], as well as Mycobacterium tuberculosis, the causative agent of human TB [5]. According to the World Health Organization (WHO) classification, bovine tuberculosis is classified as a direct zoonosis - a direct transmission of the infectious agent from the infected vertebrate (animal) to the man, a sensitive vertebrate species, without intermediate hosts [6]. Due to the direction of the transmission of the infectious agent, bovine tuberculosis can be classified into any zoonotic type [7]. Anthroponosis occurs when the transmission of the disease spreads from the animal to human, but zooanthroponosis cases, when the human is the source of the disease, are also known [5].

Tuberculosis is also one of the most widespread infectious diseases among zoo animals [8, 9]. With the number of people visiting these places, this disease poses a significant threat to public health. Tuberculosis is primarily infectious (air passages) [10]. Inhalant mycobacteria get into the lungs, where as a result of the defence mechanism, the infection is reduced, and tuberculomas typical of tuberculosis are produced in which latent bacteria can survive for many years (the comatous status).

\section{The epidemiological situation of TB in Poland}

The incidence of tuberculosis in Poland has remained at a similar level since 2000. In 2016, 6444 people became infected with all forms of tuberculosis, which is 16.8 per 100000 population (the incidence in Western Europe is less than 10 per 100,000). 103 cases of the disease have been reported in children up to 14 years of age and 76 cases in young persons aged 15-19. The highest incidence of tuberculosis in all forms was found in men in Silesia (37 per 100 000) and the lowest in women in Greater Poland Province (5.5 per 1000 000). The tuberculosis mortality rates for Poland are currently around 1.4 per 100,000. In 2014, tuberculosis was the cause of 532 deaths. The most important task of new tuberculosis control programmes is primarily its early detection [11] and the application of an appropriate anti-tuberculosis treatment [12].

What presently impedes implementing tuberculosis control programmes around the world are the phenomenon of drug resistance and the lack of new anti-tuberculosis drugs [13]. It is worth noting that the latest drug of the so-called first-line, i.e. rifampicin, was included in therapy nearly half a century ago, in 1965. Drugresistant tuberculosis, especially its variations MDR-TB (multidrug-resistant) and XDR-TB (extensively drugresistant), is a highly lethal disease. As revealed at the meeting of the Task Force Meeting on XDR TB in 2008, mortality in TB patients was about 20\%, in MDR-TB patients - 30\%, and in tuberculosis patients XDR-TB - 60\%.

The DNA fingerprinting techniques of $M$. tuberculosis, the causative agent of tuberculosis, have shown that in areas where the disease rate is high, the selected genotypes of mycobacteria dominate, which proves that the conditions for their spread are favourable. In 1995, genetically highly conserved M. tuberculosis strains were described and named Beijing. Mycobacterium tuberculosis of the Beijing genotype show some specific characteristics that facilitate their rapid spread in the world.

Beijing genotype strain of Mycobacterium tuberculosisis the most significant and most dangerous molecular family [14]. In the study conducted in 1995, approximately $80 \%$ of the strains isolated from East Asian patients (mainly in Beijing) exhibited the same DNA pattern. Soon, these strains were found in the USA, and then in Europe. Presently, Beijing strains are isolated from patients on all continents [15]. Although they have different patterns of resistance, which is highly resistant, can be found in many regions of the world. In Poland, the disease has been reported for years, mainly among immigrants [10]. In Ukraine, Beijing genotype strain of Mycobacterium tuberculosis (spoligotype 265) was isolated from the monkey (unpublished data). Taking into account only the last two centuries, it must be stated that tuberculosis has been responsible for the death of nearly 1 billion people [16].

\section{Aim of the work}

The study aimed to illustrate the use of the spoligotyping and MIRU-VNTR methods in the genetic correlations of MTBC strains isolated from 5 wild animals that were found in three Polish zoos and to identify potential transmission chains. 


\section{Material and methods}

The study material was lymph nodes and internal organs collected post mortem $(\mathrm{n}=5)$ from zoo animals: antelope (Kobus ellipsiprymnus defassa) $(\mathrm{n}=1)$, tapir anta(Tapirus terrestris) $(\mathrm{n}=2)$, alpaca (Vicugna pacos) $(\mathrm{n}=$ 1) and bison (Bison bonasus) $(\mathrm{n}=1)$ suspected of tuberculosis infection. The animals came from 3 zoos, located in the following provinces: Pomerania (1 Kob Deffasa / the zoo in Gdańsk), Lower Silesia (2 tapirs anta / the zoo in Wrocław) and Silesia (1 alpaca /the Silesian zoo in Chorzów) .

The tissue materials from the animals were subjected to an anatomopathological examination to determine the presence of tuberculous lesions, and then microbiological diagnostics consisting of the following distinct stages: culture on solid media, identification of isolated strains of mycobacteria, and a molecular analysis of Mycobacterium strains.

The strains were grown on Stonebrink's solid medium. The medium was prepared in the Laboratory of Nutrition in the National Veterinary Research Institute in Puławy. The confirmation of MTBC was done using immunochromatographic assay to detect MPT64 protein fraction secreted by MTBC cells during culture - MGIT TBC® Identification Test. Genotypic identification was performed by GenoType MTBC®, and genetic typing was established using two methods: spoligotyping and MIRU-VNTR $[17,18]$.

\section{Results}

Anatomopathological changes typical of bovine tuberculosis have been observed in the antelope and one tapir in the form of lesions. They were located in the bronchial lymph nodes. Besides, a developed form of tuberculosis was diagnosed (Table 1). The tubercles found in the lymph nodes were 1 to $5 \mathrm{~mm}$ in size. Further, the changes in the lungs were characteristic of serous pneumonia.

Table 1. Results of anatomopathological examinations

\begin{tabular}{|c|c|c|c|}
\hline No. & Animals species & $\begin{array}{l}\text { Clinical material taken for exam- } \\
\text { ination }\end{array}$ & Anatomopathological changes \\
\hline 1. & $\begin{array}{c}\text { Antelope } \\
\text { (Kobus ellipsiprymnus defassa) }\end{array}$ & Bronchial nodules, lungs & Bronchial nodules, lungs.+ \\
\hline 2. & $\begin{array}{c}\text { Tapir } \\
\text { (Tapirus terrestris) }\end{array}$ & Bronchial nodules, lungs & Bronchial nodules, lungs.+ \\
\hline 3. & $\begin{array}{c}\text { Tapir } \\
\text { (Tapirus terrestris) } \\
\end{array}$ & Bronchial nodules, lungs & - \\
\hline 4. & $\begin{array}{c}\text { Alpaca } \\
\text { (Vicugna pacos) }\end{array}$ & Bronchial nodules, lungs & - \\
\hline 5. & $\begin{array}{c}\text { Bison } \\
\text { (Bison bonasus) }\end{array}$ & $\begin{array}{l}\text { Retropharyngeal, bronchial, } \\
\text { mediastinal nodes }\end{array}$ & - \\
\hline
\end{tabular}

The tissue material was collected from all the tested animals and from each collected sample a microbial culture was obtained. Five strains of tuberculosis were isolated in the Stonebrink solid medium. All colonies were similar in appearance - they were white, morphologically indicating a bovine bacilli growth.

Among the analysed strains, 3 were identified as $M$. bovis, and 2 as $M$. caprae. Using spoligotyping, 3 types (SB1912, SB0856, SB2416) were obtained. The spiligotypes SB1912 and SB0856 are common patterns on the European continent. According to the signatures provided in the SpolDB4 database, their former names are CAP 1600 and BOV 820. The third spoligotype isolated from the antelope from Gdansk was not previously registered in international databases. To confirm the transmission of tuberculosis in the studied animal population, the MIRUVNTR method was used. The unique patterns were assigned to 3 strains and the other 2 with the same pattern were assigned to one cluster that shows the transmission of tuberculosis bacilli among animals (Table 2).

Table 2. Molecular characteristics of strains

\begin{tabular}{|c|c|c|c|}
\hline Year of isolation & Animals species, zoo location & spoligotype & MIRU-VNTR \\
\hline \multirow{2}{*}{2009} & $\begin{array}{c}\text { antelope (Gdańsk) } \\
\text { tapir (Wrocław) } \\
\text { tapir (Wrocław) }\end{array}$ & SB2416* & 462542255221136 \\
& alpaca (Chorzów) & SB1912 (CAP 1600) & 344551556413332 \\
\hline 2010 & bison (War 1600) & 344551556413332 \\
\hline 2013 & SB1912 (CAP 1600) & 422522255421192 \\
\hline
\end{tabular}

* - the pattern registered in the www.Mbovis.org database by the authors of the work 


\section{Discussion}

The results of the study indicate that tuberculosis caused by bovine mycobacteria is present in animals living in zoos in Poland. The disease poses a major threat to many animal species and, at the same time, contributes to substantial economic losses as it is identified in valuable and rare species [8]. Direct contact between the animals and the public and a large number of visitors poses significant risks to the transmission of the disease to humans. The ability to eliminate the disease through treatment is possible only in a few animal species. In 2011, Polish vets attempted to treat giraffes with active TB [19]. However, after two months of anti-tuberculosis treatment, the animal was euthanised due to its deteriorating health. In fact, most animals are eliminated when infected with the disease. The treatment of tuberculosis in animals, not isolated from visitors, is a controversial issue in terms of public health and the exposure of the staff, including the vet who administers medication every day.

The cooperation with the Polish zoos has shown that suspicious cases of this dangerous zoonosis are often not reported. The study material taken from the animals suspected of tuberculosis is commonly examined only to identify anatomopathological changes that would indicate the disease. It should be noted that such anatomopathological changes in animals should differentiate between Rhodococcus equi, Trueperella (Arcanobacterium) pyogenes, as well as MOTT (Mycobacteria other than tuberculosis) [20, 21]. The following study concerns small light yellow nodules, sometimes with abscesses in the retropharyngeal,.and under-jaw nodes, from which M. avium complex, Mycobacterium: chelonae, terrae, phlei, forruitum, Rhodococcus equi and Trueperella pyogenes were isolated.

Veterinary practitioners regard tapirs to be the indicator species that may help diagnose bovine mycobacterium infection $[22,23]$. The conducted research showed that the tapirs described in the work did not have a tuberculin skin test done before being transferred to the Silesian zoo. The molecular analysis of the material obtained from these animals showed that the isolated strains were M. caprae CAP 1600 and had identical molecular patterns as those resulting from the MIRU method. Thus, it can be assumed that the disease transmission occurred between the two individuals. According to a study by Erler et al., M. caprae spoligotype CAP 1600 is a strain that is often isolated from animals in the European continent [24]. In their research, the authors carried out a molecular analysis using the polyculture to examine 79 strains isolated from cattle, humans and wild animals in 5 countries in Central Europe. All the strains isolated from 79 animals had the same spoligotype as the above-described tapirs, i.e. M. caprae CAP 1600.

The work also confirmed a case of tuberculosis in the antelope from the Gdańsk zoo. The strain isolated from the antelope material was identified as a M. bovis with a spoligotype that was not previously registered in the international SpolDB4 database or in the veterinary register www.Mbovis.org [25]. The case was incidental, although this zoonosis was also found in the Arabian oryx (Oryx leucoryx) in 1994 in the same zoo [26].

In 2010, tuberculosis was identified in 6 antelopes and 3 giraffes in the Silesian zoo [19, 27]. The molecular analysis allowed for determining the genetic pattern of the strain isolated from alpaca, which was identical to the MIRU pattern of the strain isolated from one of the three giraffes [19]. That might indicate a common source of infection of all these animals in the Silesian institution.

There is insufficient information on sick zoo animals, their infectious diseases and unreported cases, which makes an epidemiological inquiry challenging to conduct. Consequently, the source of tuberculosis infection is also less likely to be identified.

This can be confirmed by the case of tuberculosis found in a 29-year-old female bison in the Warsaw zoo. The MIRU pattern of the isolated mycobacterium strain was identical as the ones isolated from the bison in the Bison Breeding Center in Smardzewice (unpublished data). According to Zoological Information Management System (ZIMS), the female was born in the Warsaw zoo, where she remained until her death. The source of infection in bison in Smardzewice might have been one of the females which joined the herd from the Silesian zoo in Chorzów, where she had stayed for 7 years. It cannot be ruled out however that the isolated M. caprae was present in those two Polish zoos, i.e. in Warsaw and Chorzów.

When tuberculosis is diagnosed in animals, a very thorough disinfection of all the cages and grounds in which the infected animals stayed should be administered. Also, the personnel who had contact with the sick individuals should be examined and undergo the tuberculin test, preferably in correlation with the T-SPOT.TB test [29]. In some cases, a pulmonary x-ray should be performed and an interview conducted regarding subfebrile conditions, cough, or sudden weight loss. 


\section{Conclusions}

1. The occurrence of bovine tuberculosis in zoos indicates that there is a need for greater control, both through active and passive monitoring of the animals.

2. Tuberculosis is a direct threat to human health.

\section{References:}

1. Rodriguez-Campos S, Smith NH, Boniotti MB, Aranaz A. Overview and phylogeny of Mycobacterium tuberculosis complex organisms: implication for diagnostics and legislation of bovine tuberculosis. Res Vet Sci. 2014; 97: S5-S19.

2. Parsons SDC, Drewe JA, Gey van Pittius NC, Warren RM, Van Helden PD. Novel Cause of Tuberculosis in Meerkats, South Africa. Emerg Infect Dis. 2013; doi: 10.3201/eid1912.130268.

3. Krajewska M, Weiner M, Augustynowicz-Kopeć E. Animal tuberculosis as a potential danger to men. Health Problems of Civilization. 2017; 11(1): 10-14.

4. Augustynowicz-Kopeć E, Krajewska M, Zabost A, Napiórkowska A, Zwolska Z. Characterisation of Mycobacterium bovis strains isolated from farm and wild animals from Poland. Bull Vet Inst Pulawy. 2011; 55: 381-383.

5. Krajewska M, Kozińska M, Zwolska Z, Lipiec M, Augustynowicz-Kopeć E, Szulowski K. Human as a source of tuberculosis for cattle. First evidence of transmission in Poland. Vet Microbiol. 2012; 159: 269-271.

6. Thoen C, LoBue P, de Kantor I. The importance of Mycobacterium bovis as a zoonosis. Vet Microbiol. 2006; 112: 339-345.

7. Lipiec M. Gruźlica bydła w Polsce. Puławy: Państwowy Instytut Weterynaryjny - Państwowy Instytut Badawczy; 2008 (in Polish).

8. Lewerin SS, Olsson SL, Eld K, Röken B, Ghebremichael S, Koivula T, Källenius G, Bölske G. Outbreak of Mycobacterium tuberculosis infection among captive Asian elephants in a Swedish zoo. Vet Rec. 2005; 156: 171-175.

9. Pavlik I, Machackova M, Yayo Ayele W, Lamka J, Parmova I, Melicharek I, et al. Incidence of bovine tuberculosis in wild and domestic animals other than cattle in six Central European countries during 1990-1999. Vet Med-Czech. 2002; 5: 122-131.

10. Kozińska M, Zwolska Z, Augustynowicz-Kopeć E. Transmission of drug-resistant TB among family members. Post N Med. 2011; 10: 824-830.

11. Safinowska A, Walkiewicz R, Nejman-Gryz P, Grubek-Jaworska H. Zastosowanie wybranych komercyjnych testów molekularnych w mikrobiologicznej diagnostyce gruźlicy. Pneumonol Alergol Pol. 2012; 80: 6-12 (in Polish).

12. Michałowska-Mitczuk D. Farmakoterapia gruźlicy. Postępy Farmakoterapii 2009; 65: 51-58.

13. Zwolska Z, Augustynowicz-Kopeć E. Gruźlica lekooporna. Pol Merk Lek. 2011; 30: 362-366 (in Polish).

14. Filliol I, Driscoll JR, Van Soolingen D, Kreiswirth BN, Kremer K, Valétudie G, et al. Global distribution of Mycobacterium tuberculosis spoligotypes. Emerg Infect Dis. 2002; 8: 1347-1349.

15. Glynn JR, Whiteley J, Bifani PJ, Kremer K, van Soolingen D. Worldwide occurrence of Beijing/W strains of Mycobacterium tuberculosis a systematic review. Emerg Infect Dis. 2002; 8: 843-849.

16. Ryan F. Tuberculosis: The greatest story never told. Worcestershire: Swift Publ., Great Britain, 1992.

17. Augustynowicz-Kopeć E, Jagielski T, Kozińska M, Zabost A, Zwolska Z. The significance of spoligotyping method in epidemiological investigations of tuberculosis. Pneumonol Alergol Pol. 2007; 75: 22-31.

18. Supply P, Lesjean S, Savine E, Kremer K, van Soolingen D, Locht C. Automated high-throughput genotyping for study of global epidemiology of Mycobacterium tuberculosis based on mycobacterial interspersed repetitive units. J Clin Microbiol. 2001; 39: 3563-3571.

19. Krajewska-Wędzina M, Augustynowicz-Kopeć E, Weiner M, Szulowski K. Treatment in active tuberculosis in giraffe (Giraffa camelopardalis) in Silesian Zoo and its potential consequences for public health - Case report. Ann Agr Env Med. 2017; doi: 10.26444/aaem/75685.

20. Dvorska L, Parmova I, Lavickova M, Bartl J, Vrbas V, Pavlik I. Isolation of Rhodococcus equi and atypical mycobacteria from lymph nodes of pigs and cattle in herds with the occurrence of tuberculoid gross changes in the Czech Republic over the period of 1996-1998. Vet Med-Czech. 1999; 44: 321-330.

21. Witkowski L, Orłowska B, Rzewuska M, Czopowicz M, Welz M, Anusz K, et al. Evidence of low prevalence of mycobacterial lymphadenitis in wild boars (Sus scrofa) in Poland. Acta Vet Scand. 2017; doi: 10.1186/ s13028-017-0277-0. 
22. Moser I, Prodinger WM, Hotzel H, Greenwald R, Lyashchenko KP, Bakker D, et al. Mycobacterium pinnipedii: transmission from South American sea lion (Otaria byronia) to Bactrian camel (Camelus bactrianus bactrianus) and Malayan tapirs (Tapirus indicus). Vet Microbiol. 2008; 127: 399-406.

23. Murakami PS, Monego F, Ho JL, Gibson A, Javorouski ML, Bonat M, et al. Detection of RD(Rio) strain of Mycobacterium tuberculosis in tapirs (Tapirus terrestris) from a zoo in Brazil. J Zoo Wildl Med. 2012; 43: 872-875.

24. Erler W, Martin G, Sachse K, Naumann L, Kahlau D, Beer J, et al. Molecular fingerprinting of Mycobacterium bovis subsp. caprae isolates from central Europe. J Clin Microbiol. 2004; 42: 2234 - 2238.

25. Smith $\mathrm{NH}$, Upton P. Naming spoligotype patterns for the RD9-deleted lineage of the Mycobacterium tuberculosis complex; www.Mbovis.org. Infect Genet Evol 2012; 12: 873-876.

26. Kalicki M, Rutkowiak B. Przypadek gruźlicy płuc u antylopy oryks arabski (Oryx leucoryx). Magazyn Weterynaryjny 1994; 14: 30.

27. Krajewska M, Załuski M, Zabost A, Orłowska B, Augustynowicz-Kopeć E, Anusz K, et al. Tuberculosis in Antelopes in a Zoo in Poland - Problem of Public Health. Pol J Microbiol. 2015; 4: 405-407.

28. Krajewska M, Orłowska B, Anusz K, Welz M, Bielecki W, Wojciechowska M, et al. Bovine tuberculosis in the bison herd in Smardzewice. Życie Wet. 2016; 91(1): 50-53.

29. Borkowska D, Zwolska Z, Broniarek-Samson B, Michałowska-Mitczuk D, Augustynowicz-Kopeć E. The use of IGRAs and tuberculin skin test in the diagnosis of latent tuberculosis infection. Post N Med. 2011; 10: 836841. 